\title{
Organic manures: an efficient move towards maize grain biofortification
}

\author{
Sadiq Naveed ${ }^{1,2} \cdot$ Abdur Rehim $^{2} \cdot$ Muhammad Imran $^{2} \cdot$ Muhammad Amjad Bashir $^{3} \cdot$ Muhammad Faraz Anwar $^{4}$. \\ Fiaz Ahmad ${ }^{5}$
}

Received: 6 November 2017 / Accepted: 28 February 2018 / Published online: 17 March 2018

(C) The Author(s) 2018

\begin{abstract}
Purpose In a novel approach, certain organic wastes byproducts of agro industries were assessed for their ability to support maize growth and $\mathrm{Zn}$ bioavailability in maize grain.

Methods In a field experiment, maize (Zea mays) was supplemented with farm yard manure (FYM), press mud (PM), fisheries manure (FM), and slaughter house waste (SHW) in combination with Zn soil application (ZnS) and Zn foliar spray (ZnF) with recommended doses of N:P:K (140:100:60 $\left.\mathrm{kg} \mathrm{ha}^{-1}\right)$, respectively. Besides assessing the maize growth, grain, and straw yield, $\mathrm{Zn}$ bioavailability in maize grain was also studied.

Results Organic materials combined with $\mathrm{ZnS}$ and $\mathrm{ZnF}$ significantly increased the maize yield and Zn bioavailability. $\mathrm{PM}+\mathrm{ZnS}$ increased the grain yield by $69.71 \%$, while $\mathrm{FM}+\mathrm{ZnF}$ and $\mathrm{FYM}+\mathrm{ZnF}$ increased the grain $\mathrm{Zn}$ concentration by 86.37 and $86.16 \%$, respectively. Moreover, grain $\mathrm{Zn}$ content was greatly influenced by $\mathrm{PM}+\mathrm{ZnS}$ and PM $+\mathrm{ZnF}$ resulted an average increase by $160 \%$. Phytate concentration and phytae:Zn molar ratio in grain were decreased by 30.34 and $66.92 \%$, respectively by FYM + ZnF. Estimated $\mathrm{Zn}$ bioavailability ranged from 0.92 to $2.04 \mathrm{mg} \mathrm{Zn/300} \mathrm{g}$ in maize grain, and was maximum by $\mathrm{PM}$ and FYM combined with $\mathrm{ZnF}$.

Conclusion Organic manures influence the nutrient uptake from soil, increase the product quality, and act as a good organic fertilizer. The current study revealed that organic manures can enhance crop growth and Zn uptake in grain in sustainable manner. It would be an eco-friendly approach by utilizing organic wastes annually generated by agro industries.
\end{abstract}

Keywords Biofortification $\cdot$ Maize $\cdot$ Organic manures $\cdot$ Yield $\cdot$ Zinc application

\section{Introduction}

Maize (Zea mays L.) is grown throughout the world with annual production of 875.22 million tons (FAO 2012). In Pakistan, it adds about $\geq 10 \%$ of the entire agricultural production and 15\% services (FAO 2014). Among the major crops (wheat, cotton, and rice) in Pakistan, it is fourth leading crop cultivated on one million hectares, producing 3.5 million metric tons annually (FAO 2014; PARC 2015).

\author{
Muhammad Imran \\ mimran106@yahoo.com \\ Sadiq Naveed \\ maliknaveedkalroubzu@yahoo.com \\ Abdur Rehim \\ rahimuca@yahoo.com \\ Muhammad Amjad Bashir \\ Amjad.bashir@caas.cn \\ Muhammad Faraz Anwar \\ farazji99@yahoo.com \\ Fiaz Ahmad \\ fiazahmad@bzu.edu.pk
}

1 Jiangsu Provincial Key Laboratory of Marine Biology, College of Resources and Environmental Sciences, Nanjing Agricultural University, Nanjing, People's Republic of China

2 Department of Soil Science, Bahauddin Zakariya University, Multan, Pakistan

3 Institute of Agricultural Resources and Regional Planning, Chinese Academy of Agricultural Sciences, Beijing, China

4 Soil and Water Testing Laboratory, Faisalabad, Pakistan

5 Department of Agricultural Engineering, Bahauddin Zakariya University, Multan, Pakistan 
It is a rich source of dietary fiber (72\%), proteins (10\%), and energy ( $365 \mathrm{kcal} / 100 \mathrm{~g})$ with low fat $(4 \%)$. It can be processed in a number of food ingredients such as oil, alcohol, and starch sweeteners (Ranum et al. 2014). High yielding cultivars require maximum fertilizers which led to the decline in soil fertility, nutrient use efficiency, plant available micronutrient and hampered the farming systems, and food availability in developing countries (Cakmak 2008; Jones and Healey 2010).

Zinc ( $\mathrm{Zn})$, a micronutrient, plays critical role in $\geq 300$ eukaryotic enzymes. In plants, it maintains structural veracity of proteins, and regulates auxin production, photosynthesis, nitrogen metabolism, respiration, and cell wall formation (White and Broadley 2009). In human beings, severe deficiency of $\mathrm{Zn}$ causes serious complications like growth retardation, immunity disturbance, and mental problems, specifically for children and pregnant women (Gibson 2006).

It is stated that $>25 \%$ world's population is facing shortage of $\mathrm{Zn}$, which is an alarming situation for human being and food crops (Maret and Sandstead 2006; Chasapis et al. 2012). In East Asia especially Pakistan and India, about 50-70\% population is Zn deficient, especially, in children and women (Shivay and Prasad 2012).

Maize crop is very susceptible to $\mathrm{Zn}$ scarcity and its insufficiency is ubiquitous in semi-arid areas (Singh et al. 2005). The major causes disturbing the $\mathrm{Zn}$ phytoavailability are redox potential (Eh), low $\mathrm{Zn}$ contents, high calcite, $\mathrm{pH}$, sodium ( $\mathrm{Na}$ ), calcium $(\mathrm{Ca})$, magnesium $(\mathrm{Mg})$, bicarbonate, concentration of all ligands which have ability to form organo- $\mathrm{Zn}$ complexes, biological indices in the rhizosphere, concentration of other trace metals, and availability of micro-macro specifically phosphate (P) in soil solution (Alloway 2009; Imran et al. 2016b). Indeed, mobility of $\mathrm{Zn}^{2+}$ in soils is dependent on proton actions; therefore, its mobility decreases in higher $\mathrm{pH}$ due to greater uptake ability of mineral surfaces, hydrolyzed $\mathrm{Zn}$ forms, Fe-oxide co-precipitation, and chemisorption on calcite. High $\mathrm{pH}$ is due to high concentration of calcium carbonate $\left(\mathrm{CaCO}_{3}\right)$, heavy liming, high concentration of salts, reduced conditions and content of pedogenic origin (Alloway 1995). In Pakistan (Punjab), arable land pH is about 9.2 (Muhammad et al. 2008) which ultimately decreases the availability of nutrients for plant uptake.
Potentially available solution to overcome the nutrient deficiency is the reuse of organic wastes which have potential to sustain organic matter. It is well known to bring improvements in soil microbiota functions, soil aeration, moisture retention, and availability of nutrients (Girmay et al. 2008). Many types of manures (e.g., green crop residues, mulch, industrial wastes, animal dung, and domestic wastes) have been efficiently applied to crops and resulted higher availability of $\mathrm{Zn}$ to plants by microbial actions, straight donation, or chemical conversion reactions (Maliwal et al. 2007; Quilty and Cattle 2011).

Zinc fertilizers have been widely used to enhance the crop yield and to increase $\mathrm{Zn}$ concentration in grains by various (broadcasting, foliar spray, banding, and in combinations) methods (Rehim et al. 2014; Imran et al. 2015; Sarwar et al. 2015; Imran and Rehim 2017). Foliar spray of Zn improved grain yield and increased $\mathrm{Zn}$ and starch contents (Foti et al. 2008; Imran et al. 2016a).

It is evident from the previous studies that organic matter addition in combination with soil and foliar $\mathrm{Zn}$ fertilization enhanced macro and micronutrients and contribute to increase the crop yield and nutrient uptake. However, comparisons of organic manures with regard to $\mathrm{Zn}$ bioavailability in maize grain have not been reported.

Keeping in view the above scenario, a study was planned using different organic manures and single source of $\mathrm{Zn}$ to attain best organic manure and $\mathrm{Zn}$ application method which optimize crop growth, yield, and $\mathrm{Zn}$ concentration in grain.

\section{Experimental methods}

\section{Growth conditions}

A field experiment was performed in 2015 at the research field of Faculty of Agricultural Sciences and Technology (FAST), Bahauddin Zakariya University, Multan. Soil samples were randomly collected at the depth of $0-15 \mathrm{~cm}$ prior to crop sowing for physicochemical analysis. The crop was sown on calcareous loam soil with low phytoavailable $\mathrm{Zn}$
Table 1 Physical and chemical properties of soil used in the experiment

\begin{tabular}{|c|c|c|c|}
\hline Soil property & Unit & Value & Method \\
\hline Textural class & - & Loam & USDA classification method \\
\hline Sand & $\%$ & 45.1 & Hydrometer method (Gee and Bauder 1986) \\
\hline Silt & $\%$ & 36.8 & \\
\hline Clay & $\%$ & 18.1 & \\
\hline $\mathrm{pH}_{\mathrm{s}}$ & - & 7.92 & $\mathrm{pH}$ of saturated soil paste \\
\hline $\mathrm{EC}_{\mathrm{e}}$ & $\mathrm{dS} \mathrm{m}^{-1}$ & 0.541 & Electric conductivity of saturated soil paste extract \\
\hline $\mathrm{CaCO}_{3}$ & $\%$ & 0.45 & Acid dissolution (Allison and Moodie 1965) \\
\hline OM & $\%$ & 0.51 & Walkley-Black method (Nelson and Sommers 1982) \\
\hline AB-DTPA Zn & $\mathrm{mg} \mathrm{kg}^{-1}$ & 0.63 & Extracted with AB-DTPA (Soltanpour 1985) \\
\hline
\end{tabular}


(AB-DTPA 0.63 mg Zn kg-1 soil; Table 1; Black 1965; Keeney and Nelson 1982; Whittig et al. 1986).

The study consisted on 11 treatments; Ck (without Zn and manures), FYM $+\mathrm{ZnS}$ (farm yard manure $+\mathrm{Zn}$ soil application @ $16 \mathrm{~kg} \mathrm{ha}^{-1}$ ), FYM $+\mathrm{ZnF}$ (farm yard manure $+Z n$ foliar spray $0.5 \% \mathrm{w} / \mathrm{v}$ of $\mathrm{Zn}$ solution), $\mathrm{PM}+\mathrm{ZnS}$ (press mud $+\mathrm{Zn}$ soil application @ $16 \mathrm{~kg} \mathrm{ha}^{-1}$ ), $\mathrm{PM}+\mathrm{ZnF}$ (press mud $+\mathrm{Zn}$ foliar spray $0.5 \% \mathrm{w} / \mathrm{v}$ of $\mathrm{Zn}$ solution), $\mathrm{FM}+\mathrm{ZnS}$ (fisheries manure $+\mathrm{Zn}$ soil application@16 kg ha ${ }^{-1}$ ), FM+ZnF (fisheries manure $+\mathrm{Zn}$ foliar spray $0.5 \% \mathrm{w} / \mathrm{v}$ of $\mathrm{Zn}$ solution), $\mathrm{SHW}+\mathrm{ZnS}$ (slaughter house waste+Zn soil application @ $\left.16 \mathrm{~kg} \mathrm{ha}^{-1}\right), \mathrm{SHW}+\mathrm{ZnF}$ (slaughter house waste $+Z n$ foliar spray $0.5 \% \mathrm{w} / \mathrm{v}$ of $\mathrm{Zn}$ solution), ZnS ( $\mathrm{Zn}$ soil application @ $\left.16 \mathrm{~kg} \mathrm{ha}^{-1}\right)$, and $\mathrm{ZnF}$ ( $\mathrm{Zn}$ foliar spray of $0.5 \% \mathrm{w} / \mathrm{v}$ of $\mathrm{Zn}$ solution). Nitrogen $(\mathrm{N})$, phosphorous $(\mathrm{P})$, and potassium $(\mathrm{K})$ were applied by recommended doses for maize crop (140:100:60 $\left.\mathrm{kg} \mathrm{ha}^{-1}\right)$ as Urea, DAP, and $\mathrm{K}_{2} \mathrm{SO}_{4}$, respectively. Nitrogen was applied in two splits: first at the time of sowing and second after 30 days of sowing of the crop. The suggested doses of manures $\left(10\right.$ ton ha ${ }^{-1}$ FYM, 8 ton $\mathrm{ha}^{-1} \mathrm{PM}, 2$ ton $\mathrm{ha}^{-1}$ SHW and 1 ton $\left.\mathrm{ha}^{-1} \mathrm{FM}\right)$ were applied in soil at the time of seedbed preparation. All manures were mixed thoroughly ploughing soil through rotavator. Source of $\mathrm{Zn}$ was $\mathrm{ZnSO}_{4} \cdot 7 \mathrm{H}_{2} \mathrm{O}$.

The experiment was laid out in randomized complete design (RCBD) with three replications. All plots had an area of $3 \mathrm{~m} \times 5 \mathrm{~m}$ and firm hills around to prevent intermixing of manures. Maize cv. Hybrid-6585 seed $\left(30 \mathrm{~kg} \mathrm{ha}^{-1}\right)$ was applied having plant-to-plant distance $22.5 \mathrm{~cm}$ and rowto-row distance $75 \mathrm{~cm}$. With the interval of 10 days, crop was irrigated with tube well water. Weeds were manually removed by hoeing and pesticide.

\section{Crop harvesting and chemical analysis}

Harvesting was performed at maturity and manually threshed to determine grain and stover yield. After collection of cobs and stover sub samples, each sample was washed with distilled water and dried prior to oven dry at $65^{\circ} \mathrm{C}$ for $72 \mathrm{~h}$. Wet digestion of ground samples was done in di-acid mixture of $\mathrm{HNO}_{3}: \mathrm{HClO}_{4}$ with ratio of $2: 1$. Zinc concentration of digested samples was determined with atomic absorption spectrometer (PerkinElmer, analyst 100, Waltham, USA. Phytate extraction was made with $10 \mathrm{ml}$ of $0.2 \mathrm{~N} \mathrm{HCl}$ and continuously shaking the mixture for $2 \mathrm{~h}$ at $25{ }^{\circ} \mathrm{C}$. Phytate concentration in extract was determined by indirect method (Haug and Lantzsch 1983) using a spectrophotometer (Shimadzu, UV-1201 Kyoto, Japan) at $519 \mathrm{~nm}$ wavelength.

\section{Estimated $\mathrm{Zn}$ bioavailability in grain}

Zn bioavailability from dietary intake depends on $\mathrm{Zn}$ and phytate; therefore, qualitatively estimated bioavailability was described in rice grain as ([phytate]:[Zn] ratio) (Brown et al. 2001; Weaver and Kannan 2002). While quantitative estimated bioavailability was determined by Trivariate $\mathrm{Zn}$ absorption model (Miller et al. 2007):

$$
\begin{aligned}
\mathrm{TAZ}= & 0.5\left(A_{\mathrm{MAX}}+\mathrm{TDZ}+K_{\mathrm{R}} \cdot\left(1+\mathrm{TDP} / K_{\mathrm{P}}\right)\right. \\
& -\sqrt{\left.\left(A_{\mathrm{MAX}}+\mathrm{TDZ}+K_{\mathrm{R}} \cdot\left(1+\mathrm{TDP} / K_{\mathrm{P}}\right)\right)-4 \cdot A_{\mathrm{MAX}+\mathrm{TDZ}}\right)},
\end{aligned}
$$

where $\mathrm{TAZ}=$ total daily absorbed $\mathrm{Zn} \mathrm{mg} \mathrm{day}{ }^{-1}, \mathrm{TDZ}=$ total daily dietary $\mathrm{Zn}$ mmol $\mathrm{Zn}$ day $^{-1}, A_{\mathrm{MAX}}=$ maximum $\mathrm{Zn}$ absorption $=0.091, K_{\mathrm{R}}=$ equilibrium dissociation constant of zinc-receptor-binding reaction $=0.680, K_{\mathrm{P}}=$ equilibrium dissociation constant of $\mathrm{Zn}$-phytate binding reaction $=0.033$, and TDP $=$ mmol phytate per day

Key maize consuming countries are Mexico, Zambia, and Zimbabwe; and their normal per capita maize usage is about $300 \mathrm{~g}$ per day (FAO 2013). Therefore, total daily absorbed (TAZ) was counted for $300 \mathrm{~g}$ maize flour and said "estimated Zn bioavailability". In addition, estimated bioavailability of $\mathrm{Zn}$ results is declared on the basis of adult's consumption of $300 \mathrm{~g}$ maize flour as daily intake.

\section{Statistical analysis}

All the data were statistically analyzed using "SPSS 17.0 American" software. To compare the means of all the treatments, a general linear model and analysis of the gathered data was performed by (ANOVA). Significant differences were measured by Tukey's test and graphs were made using Sigma plot version $13.00^{\circledR}$.

\section{Results}

\section{Growth parameters}

Addition of different organic manures in combination with $\mathrm{Zn}$ soil and foliar fertilization resulted in significantly $(P \leq 0.05)$ increased plant height, number of rows per cob, number of grains per cob, and cob length compared to control (Table 2). Plant height was maximum $(234.3 \mathrm{~cm})$ at $\mathrm{PM}+\mathrm{ZnS}$ followed by $\mathrm{FM}+\mathrm{ZnF}(230 \mathrm{~cm}), \mathrm{PM}+\mathrm{ZnF}$ $(227 \mathrm{~cm})$, and $\mathrm{FYM}+\mathrm{ZnS}(226 \mathrm{~cm})$, respectively, and all other treatments showed higher plant height than control $(172.60 \mathrm{~cm})($ Table 3$)$. In comparison with soil and foliar application, $\mathrm{PM}+\mathrm{ZnS}$ showed (3.22\%) higher influence than $\mathrm{PM}+\mathrm{ZnF}$ and $\mathrm{FYM}+\mathrm{ZnS}$ was $(2.26 \%)$ higher in plant height as compared with FYM $+\mathrm{ZnF}$, while $\mathrm{PM}+\mathrm{ZnS}$ was 12.11 and $10.52 \%$ greater than $\mathrm{ZnF}$ and $\mathrm{ZnS}$.

Number of rows per cob ranged (8-15.67) and number of grains per cob ranged (17.66-32.00). The maximum rows and grains per cob was noticed by $\mathrm{PM}+\mathrm{ZnS}$ and $\mathrm{PM}+\mathrm{ZnF}$, while all other treatments were at par with each other and higher in comparison with control (Table 2). Cob length was significantly higher in all treatments in comparison 
Table 2 Effect of organic manures and $\mathrm{Zn}$ fertilization on maize plant growth attributes
Table 3 Effect of organic manures and $\mathrm{Zn}$ fertilization on maize plant yield attributes

\begin{tabular}{lclll}
\hline Treatments & Plant height $(\mathrm{cm})$ & No. of rows per cob & No. of grains per cob & Cob length $(\mathrm{cm})$ \\
\hline Control & $172.60 \pm 1.52 \mathrm{~g}$ & $08.00 \pm 1.00 \mathrm{f}$ & $17.66 \pm 66 \mathrm{~h}$ & $21.20 \pm 2.30 \mathrm{~h}$ \\
$\mathrm{FYM}+\mathrm{ZnS}$ & $226.00 \pm 1.00 \mathrm{c}$ & $13.66 \pm 0.57 \mathrm{a}-\mathrm{c}$ & $28.33 \pm 1.15 \mathrm{bc}$ & $31.76 \pm 1.43 \mathrm{ab}$ \\
$\mathrm{FYM}+\mathrm{ZnF}$ & $221.00 \pm 2.00 \mathrm{~d}$ & $14.00 \pm 1.00 \mathrm{ab}$ & $27.00 \pm 1.00 \mathrm{~cd}$ & $28.56 \pm 0.58 \mathrm{~b}-\mathrm{d}$ \\
$\mathrm{PM}+\mathrm{ZnS}$ & $234.30 \pm 0.57 \mathrm{a}$ & $15.33 \pm 0.57 \mathrm{a}$ & $32.00 \pm 1.00 \mathrm{a}$ & $33.67 \pm 0.57 \mathrm{a}$ \\
$\mathrm{PM}+\mathrm{ZnF}$ & $227.00 \pm 2.00 \mathrm{bc}$ & $15.67 \pm 0.57 \mathrm{a}$ & $30.67 \pm 0.57 \mathrm{ab}$ & $30.16 \pm 1.25 \mathrm{a}-\mathrm{c}$ \\
$\mathrm{FM}+\mathrm{ZnS}$ & $221.00 \pm 2.00 \mathrm{~d}$ & $11.00 \pm 1.00 \mathrm{~cd}$ & $25.00 \pm 1.00 \mathrm{de}$ & $27.16 \pm 0.61 \mathrm{c}-\mathrm{e}$ \\
$\mathrm{FM}+\mathrm{ZnF}$ & $230.67 \pm 1.52 \mathrm{ab}$ & $12.33 \pm 1.15 \mathrm{~b}-\mathrm{d}$ & $24.00 \pm 1.00 \mathrm{ef}$ & $27.06 \pm 0.50 \mathrm{c}-\mathrm{e}$ \\
$\mathrm{SHW}+\mathrm{ZnS}$ & $217.00 \pm 1.00 \mathrm{de}$ & $12.00 \pm 1.00 \mathrm{~b}-\mathrm{d}$ & $22.00 \pm 1.00 \mathrm{fg}$ & $23.30 \pm 0.98 \mathrm{e}-\mathrm{g}$ \\
$\mathrm{SHW}+\mathrm{ZnF}$ & $220.6 \pm 2.08 \mathrm{~d}$ & $12.00 \pm 1.00 \mathrm{~b}-\mathrm{d}$ & $22.67 \pm 0.57 \mathrm{e}-\mathrm{g}$ & $22.50 \pm 1.32 \mathrm{fg}$ \\
$\mathrm{ZnS}$ & $212.60 \pm 1.52 \mathrm{ef}$ & $10.67 \pm 1.52 \mathrm{de}$ & $20.33 \pm 1.52 \mathrm{gh}$ & $25.90 \pm 1.85 \mathrm{~d}-\mathrm{f}$ \\
$\mathrm{ZnF}$ & $209.00 \pm 1.00 \mathrm{f}$ & $10.67 \pm 0.57 \mathrm{de}$ & $18.67 \pm 0.57 \mathrm{~h}$ & $21.50 \pm 2.29 \mathrm{~g}$ \\
\hline
\end{tabular}

Different letters in the same column indicate significant differences by LSD at $P \leq 0.05$ and \pm indicate standard error $(n=3)$

\begin{tabular}{llcl}
\hline Treatments & Grain yield $\left(\right.$ ton $\left.\mathrm{ha}^{-1}\right)$ & Straw yield $($ ton ha & \\
\hline Control & $3.83 \pm 0.03 \mathrm{~g}$ & $7.74 \pm 0.36 \mathrm{~h}$ & 1000-grain weight $(\mathrm{g})$ \\
FYM $+\mathrm{ZnS}$ & $5.94 \pm 0.05 \mathrm{c}$ & $11.77 \pm 0.10 \mathrm{c}$ & $177.00 \pm 0.00 \mathrm{~g}$ \\
$\mathrm{FYM}+\mathrm{ZnF}$ & $5.76 \pm 0.02 \mathrm{c}$ & $11.43 \pm 0.11 \mathrm{~d}$ & $257.66 \pm 3.00 \mathrm{c}$ \\
$\mathrm{PM}+\mathrm{ZnS}$ & $6.50 \pm 0.10 \mathrm{a}$ & $12.82 \pm 0.14 \mathrm{a}$ & $247.33 \pm 2.00 \mathrm{~d}$ \\
$\mathrm{PM}+\mathrm{ZnF}$ & $6.18 \pm 0.06 \mathrm{~b}$ & $12.34 \pm 0.15 \mathrm{~b}$ & $265.00 \pm 2.51 \mathrm{~b}$ \\
$\mathrm{FM}+\mathrm{ZnS}$ & $5.21 \pm 0.11 \mathrm{~d}$ & $10.91 \pm 0.06 \mathrm{e}$ & $274.33 \pm 1.52 \mathrm{a}$ \\
$\mathrm{FM}+\mathrm{ZnF}$ & $5.24 \pm 0.07 \mathrm{~d}$ & $10.65 \pm 0.11 \mathrm{e}$ & $217.33 \pm 2.00 \mathrm{e}$ \\
$\mathrm{SHW}+\mathrm{ZnS}$ & $4.22 \pm 0.11 \mathrm{e}$ & $10.29 \pm 0.12 \mathrm{f}$ & $220.67 \pm 1.52 \mathrm{c}$ \\
$\mathrm{SHW}+\mathrm{ZnF}$ & $4.09 \pm 0.06 \mathrm{e}$ & $10.16 \pm 0.04 \mathrm{f}$ & $205.00 \pm 2.51 \mathrm{f}$ \\
$\mathrm{ZnS}$ & $4.05 \pm 0.06 \mathrm{ef}$ & $9.81 \pm 0.04 \mathrm{~g}$ & $202.33 \pm 2.08 \mathrm{f}$ \\
$\mathrm{ZnF}$ & $4.19 \pm 0.11 \mathrm{e}$ & $9.74 \pm 0.09 \mathrm{~g}$ & $200.00 \pm 2.64 \mathrm{f}$ \\
\hline
\end{tabular}

Different letters in the same column indicate significant differences by LSD at $P \leq 0.05$ and \pm indicate standard error $(n=3)$ to control treatment (Table 3). Maximum cob length was recorded in $\mathrm{PM}+\mathrm{ZnS}(33.67 \mathrm{~cm}), \mathrm{FYM}+\mathrm{ZnS}(31.76 \mathrm{~cm})$, $\mathrm{PM}+\mathrm{ZnF}(30.16 \mathrm{~cm})$, and FYM + ZnF $(28.56 \mathrm{~cm})$, respectively (Table 2).

\section{Yield attributes}

Fertilization of $\mathrm{Zn}$ and addition of organic manures significantly $(P \leq 0.05)$ produced high grain and stover yield and thousand grain weight. Grain yield by $\mathrm{PM}+\mathrm{ZnS}, \mathrm{PM}+\mathrm{ZnF}$, $\mathrm{FYM}+\mathrm{ZnS}$, and FYM + ZnF was 69.71, 61.79, 55.09, and $50.39 \%$, respectively, higher than control (Table 3). While, among the treatments, $\mathrm{PM}+\mathrm{ZnS}$ was $6.09,9.43$, and $50 \%$ higher than $\mathrm{PM}+\mathrm{ZnF}, \mathrm{FYM}+\mathrm{ZnS}$, and $\mathrm{ZnS}$, respectively (Table 3).

Stover yield ranged 7.740-12.82 ton $\mathrm{ha}^{-1}$. It was maximum in $\mathrm{PM}+\mathrm{ZnS}\left(12.82\right.$ ton $\left.\mathrm{ha}^{-1}\right)$, followed by $\mathrm{PM}+\mathrm{ZnF}$ (12.34 ton $\left.\mathrm{ha}^{-1}\right), \mathrm{FYM}+\mathrm{ZnS}\left(11.77\right.$ ton ha $\left.{ }^{-1}\right), \mathrm{FYM}+\mathrm{ZnF}$ (11.43 ton $\left.\mathrm{ha}^{-1}\right)$, and SHW $+\mathrm{ZnS}\left(10.91\right.$ ton ha $\left.{ }^{-1}\right)$.Various organic manures and $\mathrm{Zn}$ fertilization methods showed significant difference in 1000-grain weight. It ranged 177-274 g (Table 3 ). It was mainly influenced by $\mathrm{PM}+\mathrm{ZnF}$ and FYM $+\mathrm{ZnS}$, while all other treatments had greater 1000grain weight as compared with control. In contrast to the $\mathrm{Zn}$ soil and foliar application, Zn soil application had more 1000-grain weight as compared with foliar application (Table 3).

\section{Zinc concentration in grain and stover}

Various organic amendments and $\mathrm{Zn}$ appliance significantly $(P \leq 0.05)$ enhanced $\mathrm{Zn}$ concentration in grains and stover (Table 4). Zinc concentration in grains ranged (19.26-36.06 mg kg${ }^{-1}$ ) among the treatments. Zinc concentration was $86.37,86.16,80.28$, and $74.6 \%$ higher in $\mathrm{FM}+\mathrm{ZnF}, \mathrm{FYM}+\mathrm{ZnF}, \mathrm{PM}+\mathrm{ZnF}$, and $\mathrm{PM}+\mathrm{ZnS}$, respectively, as compared to control, while between the treatments $\mathrm{FM}+\mathrm{ZnF}$ was $10 \%$ higher than $\mathrm{FYM}+\mathrm{ZnS}$ and $6.6 \%$ higher 
Table 4 Effect of organic manures and $\mathrm{Zn}$ fertilization on $\mathrm{Zn}$ conc. in grains, stover, and $\mathrm{Zn}$ contents in grains and accumulation in shoot

\begin{tabular}{lllll}
\hline Treatments & $\begin{array}{l}\text { Zn concentration in } \\
\text { grain }\left(\mathrm{mg} \mathrm{kg}^{-1}\right)\end{array}$ & $\begin{array}{l}\text { Zn concentration in } \\
\text { stover }\left(\mathrm{mg} \mathrm{kg}^{-1}\right)\end{array}$ & $\begin{array}{l}\text { Zn content in grain } \\
\left(\mu \mathrm{g} \mathrm{seed}^{-1}\right)\end{array}$ & $\begin{array}{l}\text { Zn accumulation } \\
\text { in shoot }\left(\mathrm{g} \mathrm{ha}^{-1}\right)\end{array}$ \\
\hline Control & $19.37 \pm 1.68 \mathrm{c}$ & $16.55 \pm 1.97 \mathrm{~b}$ & $3.42 \pm 0.25 \mathrm{~d}$ & $202.32 \pm 11.51 \mathrm{f}$ \\
$\mathrm{FYM}+\mathrm{ZnS}$ & $32.66 \pm 2.57 \mathrm{ab}$ & $32.97 \pm 1.72 \mathrm{a}$ & $8.41 \pm 0.61 \mathrm{a}$ & $582.10 \pm 2.90 \mathrm{~b}$ \\
$\mathrm{FYM}+\mathrm{ZnF}$ & $36.06 \pm 3.04 \mathrm{a}$ & $34.79 \pm 3.66 \mathrm{a}$ & $8.92 \pm 0.08 \mathrm{a}$ & $605.72 \pm 27.91 \mathrm{ab}$ \\
$\mathrm{PM}+\mathrm{ZnS}$ & $33.82 \pm 4.47 \mathrm{a}$ & $34.20 \pm 2.82 \mathrm{a}$ & $8.96 \pm 1.21 \mathrm{a}$ & $658.33 \pm 23.68 \mathrm{a}$ \\
$\mathrm{PM}+\mathrm{ZnF}$ & $34.92 \pm 1.65 \mathrm{a}$ & $33.68 \pm 2.49 \mathrm{a}$ & $9.57 \pm 1.77 \mathrm{a}$ & $631.95 \pm 8.96 \mathrm{ab}$ \\
$\mathrm{FM}+\mathrm{ZnS}$ & $26.83 \pm 2.79 \mathrm{abc}$ & $19.56 \pm 2.06 \mathrm{~b}$ & $5.82 \pm 0.55 \mathrm{bc}$ & $353.44 \pm 27.31 \mathrm{~cd}$ \\
$\mathrm{FM}+\mathrm{ZnF}$ & $36.10 \pm 1.34 \mathrm{a}$ & $20.58 \pm 2.23 \mathrm{~b}$ & $7.96 \pm 0.34 \mathrm{ab}$ & $408.80 \pm 16.07 \mathrm{c}$ \\
$\mathrm{SHW}+\mathrm{ZnS}$ & $21.90 \pm 2.54 \mathrm{c}$ & $21.03 \pm 1.46 \mathrm{~b}$ & $4.49 \pm 0.53 \mathrm{~cd}$ & $308.77 \pm 11.81 \mathrm{de}$ \\
$\mathrm{SHW}+\mathrm{ZnF}$ & $19.26 \pm 1.97 \mathrm{c}$ & $22.14 \pm 2.46 \mathrm{~b}$ & $3.89 \pm 0.35 \mathrm{~cd}$ & $303.84 \pm 31.07 \mathrm{de}$ \\
$\mathrm{ZnS}$ & $23.85 \pm 1.85 \mathrm{bc}$ & $19.62 \pm 0.58 \mathrm{~b}$ & $4.77 \pm 0.40 \mathrm{~cd}$ & $289.31 \pm 10.63 \mathrm{e}$ \\
$\mathrm{ZnF}$ & $21.50 \pm 2.58 \mathrm{c}$ & $17.80 \pm 2.07 \mathrm{~b}$ & $4.35 \pm 0.50 \mathrm{~cd}$ & $261.86 \pm 20.61 \mathrm{e}$ \\
\hline
\end{tabular}

Different letters in the same column indicate significant differences by LSD at $P \leq 0.05$ and \pm indicate standard error $(n=3)$ than $\mathrm{PM}+\mathrm{ZnS}$ (Table 4). In stover, maximum Zn concentration was recorded in $\mathrm{FYM}+\mathrm{ZnF}\left(34.79 \mathrm{mg} \mathrm{kg}^{-1}\right)$, followed by $\mathrm{FYM}+\mathrm{ZnF}\left(34.79 \mathrm{mg} \mathrm{kg}^{-1}\right), \mathrm{PM}+\mathrm{ZnS}\left(34.20 \mathrm{mg} \mathrm{kg}^{-1}\right)$, and $\mathrm{PM}+\mathrm{ZnF}\left(33.68 \mathrm{mg} \mathrm{kg}^{-}\right.$) , and minimum in control $\left(16.55 \mathrm{mg} \mathrm{kg}^{-1}\right)$. Zinc concentration in stover was less than in grains. Maximum increase in $\mathrm{Zn}$ content of maize grains was $(179.82 \%)$ by $\mathrm{PM}+\mathrm{ZnF}$ followed by, $161,160.82,145$, and $132.75 \%$ by PM $+\mathrm{ZnS}, \mathrm{FYM}+\mathrm{ZnF}, \mathrm{FYM}+\mathrm{ZnS}$, and $\mathrm{FM}+\mathrm{ZnF}$, respectively, as compared with control.

Zinc accumulation in shoot was also significant $(P \leq 0.05)$ than control in all treatments (Table 4) ranging from 202.32 to $658.33 \mathrm{~g} \mathrm{ha}^{-1}$. In contrast to $\mathrm{Zn}$ soil and foliar application in combination with organic manures, $\mathrm{Zn}$ soil application showed more $\mathrm{Zn}$ accumulation in shoot $658.33 \mathrm{~g} \mathrm{ha}^{-1}$.

\section{Phytate concentration in grain}

Phytate concentration in grain varied among all the treatments. It was significantly $(P \leq 0.05)$ higher in control in comparison with other treatments (Fig. 1a). Maximum decrease in phytate concentration was recorded in $\mathrm{FYM}+\mathrm{ZnF}(30.34 \%)$ and $\mathrm{PM}+\mathrm{ZnS}(26.83 \%)$. In all other treatments, phytate concentration was less as compared to control (13.68 $\mathrm{mg} \mathrm{g}^{-1}$ ) (Fig. 1a). Phytate content in grains significantly differed among all the treatments (Fig. 1b). It ranged from 2.15 to $2.65 \mathrm{mg} \mathrm{seed}^{-1}$. Maximum phytate content was in $\mathrm{PM}+\mathrm{ZnS}$, while minimum in $\mathrm{SHW}+\mathrm{ZnF}$ (Fig. 1b) as compared with control. Phytate content in grain $\left(\mathrm{kg} \mathrm{ha}^{-1}\right)$ was significantly different for each treatment. Press mud combined with $\mathrm{Zn}$ soil application $(\mathrm{PM}+\mathrm{ZnS})$ has maximum phytate content increase percentage (24\%) followed by FYM $+\mathrm{ZnS}(15.74 \%)$ and all other treatments have higher phytate content in grains as compared with control (Fig. 1c).
Various organic amendments and $\mathrm{Zn}$ appliance significantly $(P \leq 0.05)$ decreased grain [phytate]: [Zn] molar ratio (Fig. 2a). Maximum decrease in phytate: $\mathrm{Zn}$ molar ratio was recorded in $\mathrm{FYM}+\mathrm{ZnF}(66.92 \%), \mathrm{PM}+\mathrm{ZnS}(65.56 \%)$, $\mathrm{PM}+\mathrm{ZnS}(64.73 \%)$, and in $\mathrm{FYM}+\mathrm{ZnS}(62.77 \%)$ as compared with control.

\section{Estimated Zn bioavailability}

Different organic manures and soil fertilization and foliar spray of $\mathrm{Zn}$ significantly influenced $(P \leq 0.05)$ the predictable $\mathrm{Zn}$ bioavailability in maize grains (Fig. 2b). Maximum estimated bioavailability of $\mathrm{Zn}$ was $2.04 \mathrm{mg}$ for $300 \mathrm{~g}$ maize grain at $\mathrm{FYM}+\mathrm{ZnF}$ followed by $\mathrm{PM}+\mathrm{ZnF}(1.99 \mathrm{mg} / 300 \mathrm{~g})$ and $\mathrm{PM}+\mathrm{ZnS}(1.97 \mathrm{mg} / 300 \mathrm{~g})$, and minimum at control $(0.92 \mathrm{mg} / 300 \mathrm{~g})$.

\section{Relative yield}

Organic amendments with $\mathrm{Zn}$ application significantly $(P \leq 0.05)$ influenced relative yield $(\%)$. Maximum relative yield was recorded by $\mathrm{PM}+\mathrm{ZnS}(100 \%)$ followed by $\mathrm{PM}+\mathrm{ZnF}(95 \%), \mathrm{FYM}+\mathrm{ZnS}(91 \%), \mathrm{FYM}+\mathrm{ZnF}(89 \%)$, and $\mathrm{FM}+\mathrm{ZnF}(81 \%)$ as compared with control (59\%). All other treatments' relative yield was higher than control (Fig. 3).

\section{Discussion}

Most of the Pakistani arable soils are Zn deficient (Imran et al. 2016a; b) the same is the case with this experimental soil ( $\leq 1 \mathrm{mg}$ AB-DTPA extractable $\mathrm{Zn}$ per $\mathrm{kg}$ of soil; Table 1). The major factors contributing to low bioavailability of $\mathrm{Zn}$ might be parent material, low $\mathrm{Zn}$ content in 

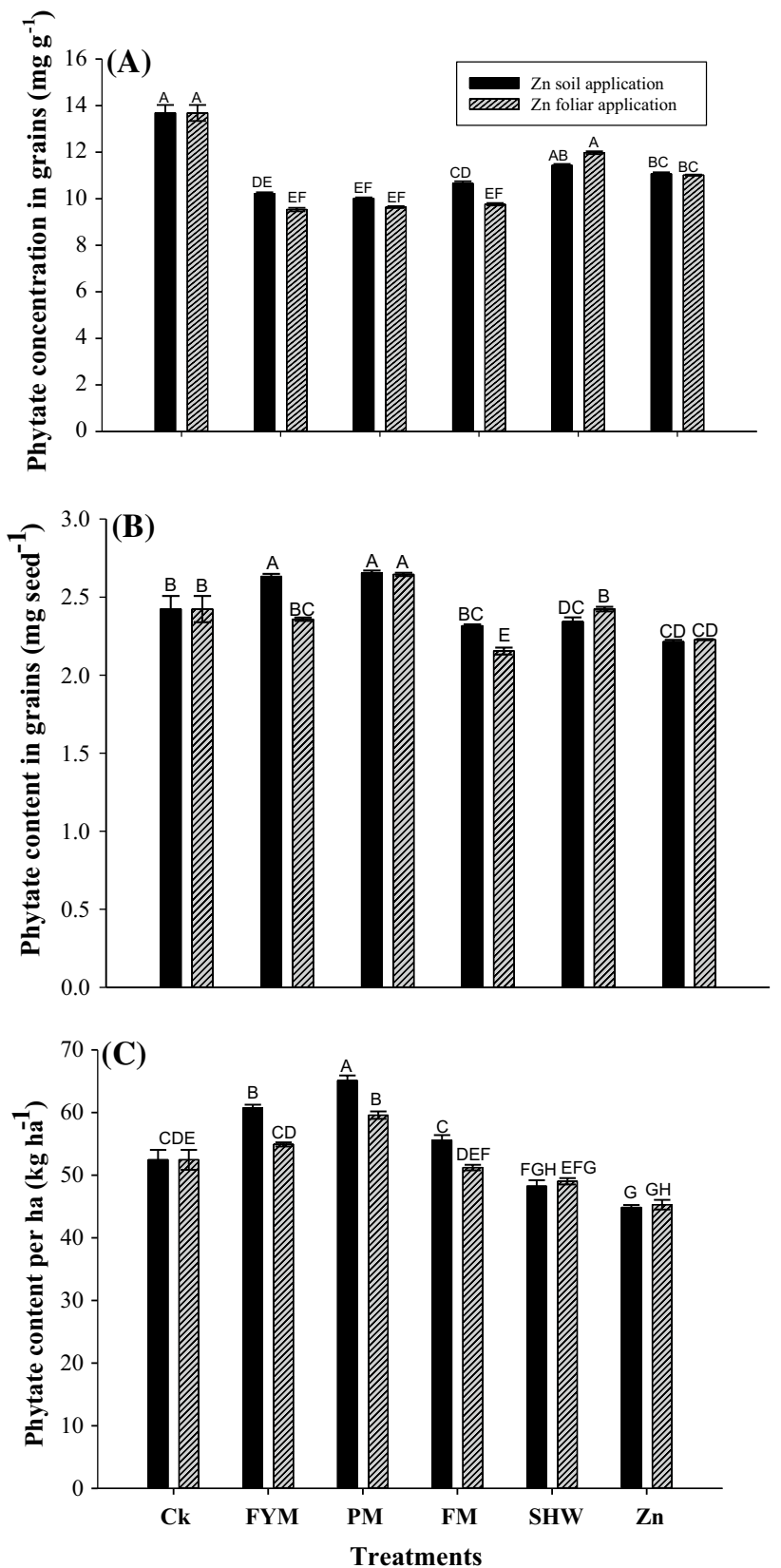

Fig. 1 Effect of organic manures and $\mathrm{Zn}$ fertilization on phytate concentration (a), phytate content (b), and phytate content per ha (c). Different letters indicate significant differences by LSD at $P \leq 0.05$ and error bars indicate \pm standard error $(n=3)$

soil, high $\mathrm{pH}$, low organic matter, highly weathered, soil erosion, and coarse textured soils (Singh et al. 2005; Ryan et al. 2013). Organic manures are the potential source of micro-macro nutrients, increase microbial activities, modify the soil physical behaviour, and influence the availability of applied nutrients (Pandey et al. 2007). Combined use of organic manures and $\mathrm{Zn}$ make readily availability of $\mathrm{Zn}$, healthy growth of roots, and maintain the adequate uptake of $\mathrm{Zn}$ (Patil et al. 2017).
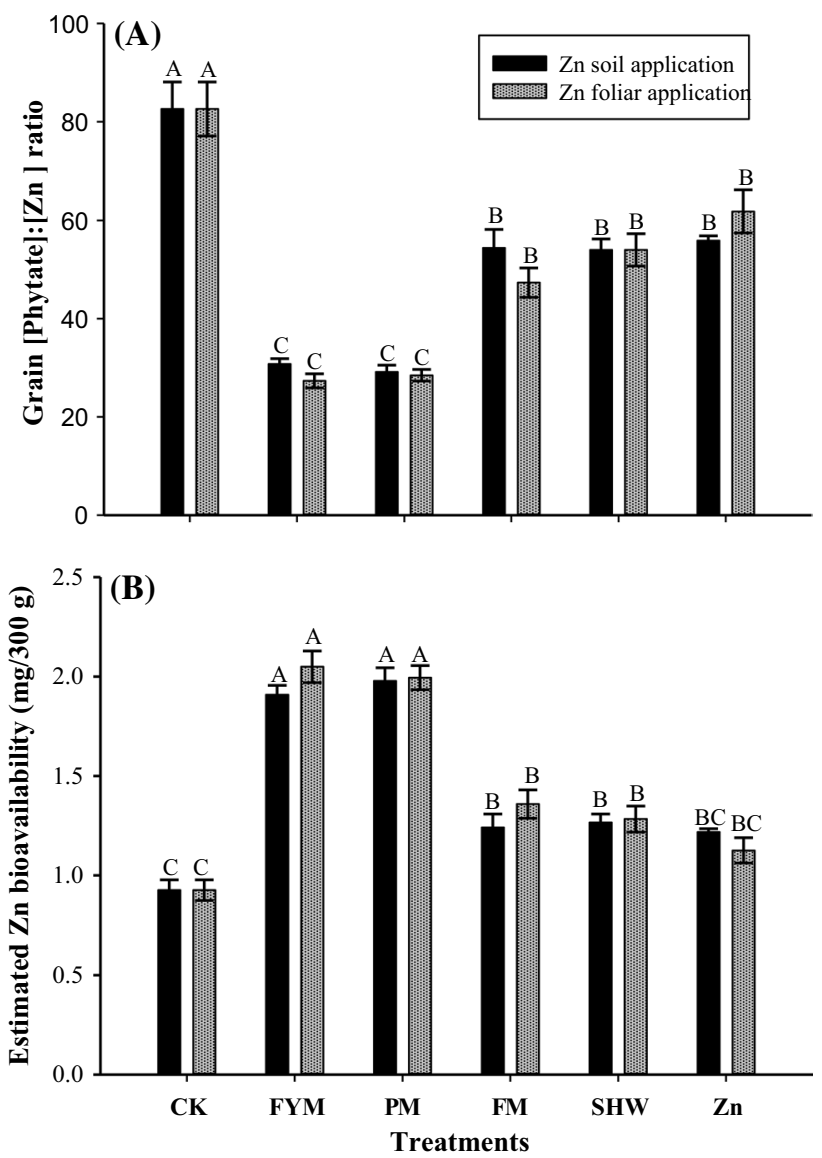

Fig. 2 Effect of organic manures and $\mathrm{Zn}$ fertilization on grain phytate Zn molar ratio (a) and estimated Zn bioavailability (b). Different letters indicate significant differences by LSD at $P \leq 0.05$ and error bars indicate \pm standard error $(n=3)$

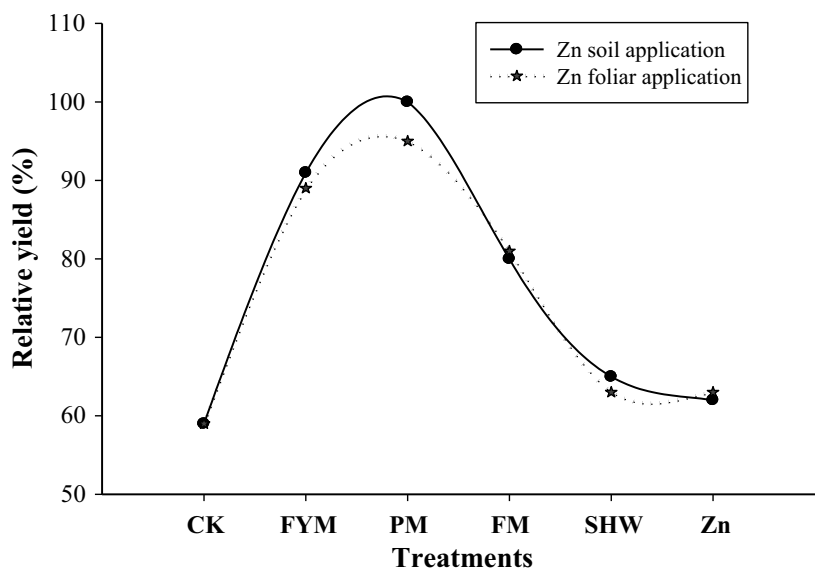

Fig. 3 Effect of organic manures and $\mathrm{Zn}$ fertilization on relative yield (\%) of maize crop 
Improvement in plant growth was unexpected as $\mathrm{Zn}$ scarcity in soil ( $0.63 \mathrm{mg} \mathrm{kg}^{-1}$ soil; Table 2$)$. Organic amendments and $\mathrm{Zn}$ application significantly $(P \leq 0.05)$ enhanced the crop growth and yield (Table 2). Application of organic manures improved the soil physicochemical properties such as change in soil $\mathrm{pH}$ and organic complex formation and make readily availability of $\mathrm{Zn}$ for plant uptake (Rehman et al. 2012). Application of $\mathrm{Zn}$ (soil and foliar) with press mud addition enhanced crop production (khan et al. 2015). In this study, improved crop productivity is due to the supply of macro (NPK) and micronutrient $(\mathrm{Zn}, \mathrm{Fe}, \mathrm{Cu}$, and $\mathrm{Mn})$ through nutrient-enriched press mud having potential to activate the microbial activities in soil rhizosphere making the readily availability of nutrients to rhizospheric microbes which ultimately increase the soil enzymatic activity and increase the phytoavailability of required nutrients to the crop and increase the crop growth (Bangar et al. 2000; Rakkiyappan et al. 2001). Second reason for the more growth and yield of maize is the application of $\mathrm{Zn}$ with press mud, because, for plants, $\mathrm{Zn}$ is necessary for auxin synthesis which elongates the plant cell and enhances the cell growth (Imran and Rehim 2017). Several other studies have reported that addition of organic manures (farm manure, press mud, green manure, and crop residue) can significantly enhance the cereal crop growth and yield providing essential macro as well as micronutrients (Agbede et al. 2008; Wang et al. 2012). These all studies make stronger our results that addition of organic manures with $\mathrm{Zn}$ fertilization can promote plant growth and enhance the crop yields.

Bioavailability of $\mathrm{Zn}$ in maize grains and stover was significantly $(P \leq 0.05)$ increased by addition of organic manures and $\mathrm{Zn}$ fertilization (Table 4). This increase in $\mathrm{Zn}$ grain concentration, $\mathrm{Zn}$ stover concentration, $\mathrm{Zn}$ content, and $\mathrm{Zn}$ accumulation in shoots indicates that all the manures have potential to increase the phytoavailability of $\mathrm{Zn}$ to maize crop. It might be due to application of $\mathrm{Zn}$ enriched manures with $\mathrm{Zn}$ fertilization, because organic manures in soil influence the microbial population which can enhance $\mathrm{Zn}$ content in rhizosphere by changing soil chemistry and release at time for plant uptake (Tejada et al. 2006; Zhang et al. 2013; Patil et al. 2017). Foliar spray of $\mathrm{Zn}\left(1840 \mathrm{~g} \mathrm{ha}^{-1}\right)$ and $\left(1500 \mathrm{~g} \mathrm{ha}^{-1}\right)$ resulted in increase of $28-68 \%$ and $61 \%$, respectively, $\mathrm{Zn}$ in wheat (Zhang et al. 2010; Zhao et al. 2014). Therefore, organic manures specifically, farm yard manure, fisheries manure, and press mud along with $\mathrm{Zn}$ foliar and soil fertilization can influence the availability of $\mathrm{Zn}$ to shoot and grains of maize crop.

Phytic acid (hexakisphosphoric acid) accumulates mainly in seeds and grains in the form of phosphate during ripening period, which has strong capacity to chelate the cations which adversely decrease the bioavailability of $\mathrm{Zn}$ to mammalians (Lonnerdal 2002; Fredlund et al. 2006).
Our results stated that phytate concentration in grains and phytate content were significantly $(P \leq 0.05)$ decreased (Fig. 1a-c) when organic manures were applied with $\mathrm{Zn}$ soil and foliar method. This decrease in phytate concentration is strongly supported by findings of (Imran et al. 2015; Imran and Rehim 2017).

Organic amendments and $\mathrm{Zn}$ application significantly $(P \leq 0.05)$ reduced the [phytate]:[Zn] molar ratio (Fig. 2a). These results indicate that addition of organic manures with $\mathrm{Zn}$ fertilization has potential to decrease grain phytate zinc molar ratio and increase the bioavailable $\mathrm{Zn}$ in maize grains. It might be due to the increase in grain yield and fertilization of Zn (Imran and Rehim 2017).

Application of various organic manures and $\mathrm{Zn}$ soil and foliar application methods increased the estimated bioavailability up to $(2.04 \mathrm{mg} / 300 \mathrm{~g}$ maize grain $)$ using trivariate model (Miller et al. 2007; Fig. 2b). Therefore, it can be stated that biofortification of maize by $\mathrm{Zn}$ soil and foliar fertilization along with organic amendments could meet the recommended dietary intake of $\mathrm{Zn}$ for human beings ( $3 \mathrm{mg}$ per day; Institute of Medicine 2001).

There was a significant $(P \leq 0.05)$ role of organic manures and $\mathrm{Zn}$ application on relative yield (\%) of maize crop (Fig. 3). PM $+\mathrm{ZnS}$ showed (100\%) increase in relative yield followed by $\mathrm{PM}+\mathrm{ZnF}(95 \%)$ and all other treatments had greater yield as compared with control. This clearly demonstrated that organic manures' addition and $\mathrm{Zn}$ soil and foliar application have pronounced effects on grain yield of maize crop.

\section{Conclusion}

Addition of organic manures with $\mathrm{Zn}$ fertilization methods (soil and foliar) seems an effective approach for biofortification of maize crop. Maximum grain yield was increased $\mathrm{PM}+\mathrm{ZnS}$ and maximum $\mathrm{Zn}$ concentration was increased by $\mathrm{FM}+\mathrm{ZnF}$. Estimated bioavailability was also greatly influenced by the FYM $+\mathrm{ZnF}$. Among the organic manures and $\mathrm{Zn}$ application methods, FYM and foliar spray are more effective to upsurge $\mathrm{Zn}$ bioavailability and $\mathrm{Zn}$ density in maize grain. Conclusively, soil and foliar Zn fertilization of maize in combination with organic manures would be an adorable way to get the desired yield and $\mathrm{Zn}$ concentration in maize grains.

Acknowledgements We would like to give our deep thanks to Professor Ying Ge from Jiangsu Provincial Key Laboratory of Marine Biology, College of Resources and Environmental Sciences, Nanjing Agricultural University, Nanjing, People's Republic of China, for his kind guidance and support for this study. 
Open Access This article is distributed under the terms of the Creative Commons Attribution 4.0 International License (http://creativeco mmons.org/licenses/by/4.0/), which permits unrestricted use, distribution, and reproduction in any medium, provided you give appropriate credit to the original author(s) and the source, provide a link to the Creative Commons license, and indicate if changes were made.

\section{References}

Agbede T, Ojeniyi S, Adeyemo A (2008) Effect of poultry manure on soil physical and chemical properties, growth and grain yield of sorghum in southwest, Nigeria. Am J Sustain Agric 2:72-77. https ://doi.org/10.1016/j.still.2008.12.014

Allison LE, Moodie CD (1965) Carbonate. In: Black CA (ed) Methods of soil analysis, part 2: Chemical and microbiological properties. ASA SSSA Madison, WI USA, pp 1379-1396

Alloway B (1995) Heavy metals in soils, 2nd edn. Blackie Academic \& Professional, New York. https://doi. org/10.1007/978-94-011-1344-1

Alloway B (2009) Soil factors associated with zinc deficiency in crops and humans. Environ Geochem Health 31:537-548. https://doi. org/10.1007/s10653-009-9255-4

Bangar K, Parmar B, Ashok M (2000) Effect of nitrogen and pressmud cake application on yield and uptake of N, P and $\mathrm{K}$ by sugarcane (Saccharum officinarum L.). Crop Res 19:198-203. https://doi. org/10.4172/2329-8863.1000153

Black CA (1965) Methods of soil analysis part 1 and 2. Amc. Soc. Agron. USA. https://doi.org/10.1097/00010694-19651 $1000-00020$

Brown KH, Wuehler SE, Peerson JM (2001) The importance of zinc in human nutrition and estimation of the global prevalence of zinc deficiency. Food Nutr Bull 22:113-125. https://doi. org/10.1177/156482650102200201

Cakmak I (2008) Enrichment of cereal grains with zinc: agronomic or genetic biofortification? Plant Soil 302:1-17. https://doi. org/10.1177/156482650102200201

Chasapis CT, Loutsidou AC, Spiliopoulou CA, Stefanidou ME (2012) Zinc and human health: an update. Arch Toxicol 86:521-534. https://doi.org/10.1007/s00204-011-0775-1

Food and Agriculture Organization (FAO) (2012) Production. http:// faostat.fao.org/site/567/. Accessed 12 Feb 2014

Food and Agriculture Organization (FAO) (2013) Food and Agricultural Organization. https://doi.org/10.4135/9781412939591.n445

Food and Agriculture Organization (FAO) (2014). ftp://ftp.fao.org/ docrep/fao/004/y3841e00.pdf. https://doi.org/10.1787/agr_outlo ok-2014-es

Foti R, Abureni K, Tigere A, Gotosa J, Gere J (2008) The efficacy of different seed priming osmotica on the establishment of maize (Zea mays L.) caryopses. J Arid Environ 72:1127-1130. https:// doi.org/10.1016/j.jaridenv.2007.11.008

Fredlund K, Isaksson M, Rossander-Hulthen L, Almgren A, Sandberg A-S (2006) Absorption of zinc and retention of calcium: dosedependent inhibition by phytate. J Trace Elem Med Bio 20:49-57. https://doi.org/10.1016/j.jtemb.2006.01.003

Gee GW, Bauder JW (1986) Hydrometer method. Methods of Soil Analysis: Part, pp 404-408. https://dl.sciencesocieties.org/publi cations/books/pdfs/sssabookseries/methodsofsoilan1/383

Gibson RS (2006) Zinc: the missing link in combating micronutrient malnutrition in developing countries. Proc Nutr Soc 65:51-60. https://doi.org/10.1079/pns2005474

Girmay G, Singh B, Mitiku H, Borresen T, Lal R (2008) Carbon stocks in Ethiopian soils in relation to land use and soil management. Land Degrad Dev 19:351-367. https://doi.org/10.1002/ldr.844
Haug W, Lantzsch HJ (1983) Sensitive method for the rapid determination of phytate in cereals and cereal products. J Sci Food Agr 34:1423-1426. https://doi.org/10.1002/jsfa.2740341217

Imran M, Rehim A (2017) Zinc fertilization approaches for agronomic biofortification and estimated human bioavailability of zinc in maize grain. Arch Agron Soil Sci 63:106-116. https://doi. org/10.1080/03650340.2016.1185660

Imran M, Kanwal S, Hussain S, Aziz T, Maqsood MA (2015) Efficacy of zinc application methods for concentration and estimated bioavailability of zinc in grains of rice grown on a calcareous soil. Pak J Agric Sci 52:169-175. http://www.pakjas.com.pk

Imran M, Rehim A, Hussain S, Zafar ul Hye M, Rehman HU (2016a) Efficiency of zinc and phosphorus applied to open-pollinated and hybrid cultivars of maize. Int J Agric Biol 18:1249-1255. https:// doi.org/10.17957/JJAB/15.0239

Imran M, Rehim A, Sarwar N, Hussain S (2016b) Zinc bioavailability in maize grains in response of phosphorous-zinc interaction. J Plant Nutr Soil Sc 179:60-66. https://doi.org/10.1002/ jpln. 201500441

Jones DL, Healey JR (2010) Organic amendments for remediation: putting waste to good use. Elements 6:369-374. https://doi. org/10.2113/gselements.6.6.369

Keeney DR, Nelson DW (1982) Nitrogen-Inorganic Forms 1. Methods of soil analysis. Part 2. Chemical and microbiological properties methods of soil analysis, pp 643-698. https://dl.scien cesocieties.org/publications/books/abstracts/agronomymonogra /methodsofsoilan2/643

Khan KP, Memon KS, Memon M, Khan KS (2015) Nutrient availability and maize growth in soil amended with mineral fertilizers and pressmud biocompsot. 5. http://creativecommons.org/ licenses/bync/3.0/)

Lonnerdal B (2002) Phytic acid-trace element ( $\mathrm{Zn}, \mathrm{Cu}, \mathrm{Mn}$ ) interactions. Int J Food Sci Technol 37:749-758. https://doi.org/10.10 46/j.1365-2621.2002.00640.x

Maliwal P, Maliwal P, Mundra S (2007) Agronomy at a glance, 3rd edn, vol 2. Agrotech Pub. Academy. http://www.kopykitab.com/ product/6971

Maret W, Sandstead HH (2006) Zinc requirements and the risks and benefits of zinc supplementation. J Trace Elem Med Bio 20:3-18. https://doi.org/10.1016/j-.jtemb.2006.01.006

Miller LV, Krebs NF, Hambidge KM (2007) A mathematical model of zinc absorption in humans as a function of dietary zinc and phytate. J Nutr 137:135-141. https://doi.org/10.1017/s0007 $11451200195 x$

Muhammad S, Muller T, Joergensen R (2008) Relationships between soil biological and other soil properties in saline and alkaline arable soils from the Pakistani Punjab. J Arid Environ 72:448457. https://doi.org/10.1016/j.jaridenv.2007.06.016

Nelson DW, Sommers LE (1982) Total carbon, organic carbon and organic matter. In: Klute A (ed) Methods of soil analysis, part 2: chemical and microbiological properties. Agronomia. Monograph 9. Soil Science Society of America, Madison, pp 570-571

Pakistan Agriculture Research Council (PARC) (2015) Annual reports. https://doi.org/10.1787/9789282106013-graph49-fr. www.parc.gov.pk/

Pandey N, Verma A, Tripathi R (2007) Integrated nutrient management in transplanted hybrid rice (Oryza sativa). Indian J Agron 52:40-42. https://doi.org/10.3126/ajn.v3i0.9006

Patil S, Girijesh G, Nandini K, Kumar K, Pradeep L, Kumar TR (2017) Effect of zinc application through soil and foliar means on bio-fortification of zinc in rainfed maize (Zea mays L.). Int J Pure Appl Biol Sci 5:246-253. https://doi.org/10.18782 /2320-7051.2471

Quilty J, Cattle S (2011) Use and understanding of organic amendments in Australian agriculture. Rev Soil Res 49:1-26. https:// doi.org/10.1071/sr10059 
Rakkiyappan P, Thangavelu S, Malathi R, Radhamani R (2001) Effect of biocompost and enriched pressmud on sugarcane yield and quality. Sugar Tech 3:92-96. https://doi.org/10.1007/bf03014569

Ranum P, Pena-Rosas JP, Garcia-Casal MN (2014) Global maize production, utilization, and consumption. Ann N Y Acad Sci 1312:105-112. https://doi.org/10.1111/nyas.12396

Rehim A, Zafar-ul-Hye M, Imran M, Ali M, Hussain M (2014) Phosphorous and zinc application improves rice productivity. Pak J Sic 66:134-139

Rehman H-U, Aziz T, Farooq M, Wakeel A, Rengel Z (2012) Zinc nutrition in rice production systems. Rev Plant Soil 361:203-226. https://doi.org/10.1007/s11104-012-1346-9

Ryan J, Rashid A, Torrent J, Yau SK, Ibrikci H, Sommer R, Erenoglu EB, Sparks D (2013) Micronutrient constraints to crop production in the Middle East-West Asia region: significance, research, and management. Adv Agron 122:1-84. https://doi.org/10.1016/ b978-0-12-417187-9.00001-2

Sarwar N, Ishaq W, Farid G, Shaheen MR, Imran M, Geng M, Hussain S (2015) Zinc-cadmium interactions: impact on wheat physiology and mineral acquisition. Ecotoxicol Environ Saf 122:528-536

Shivay YS, Prasad R (2012) Zinc-coated urea improves productivity and quality of basmati rice (Oryza sativa $\mathrm{L}$.) under zinc stress condition. J Plant Nutr 35:928-951. https://doi.org/10.1080/01904 167.2012.663444

Singh B, Natesan SKA, Singh BK, Usha K (2005) Improving zinc efficiency of cereals under zinc deficiency. Curr Sci 88:36-44. http:// www.jstor.org/stable/24110091?seq=1\#page_scan_tab_contents

Soltanpour P (1985) Use of ammonium bicarbonate DTPA soil test to evaluate elemental availability and toxicity. Commun Soil Sci Plant 16:323-338. https://doi.org/10.1080/-00103628509367607

Tejada M, Hernandez M, Garcia C (2006) Application of two organic amendments on soil restoration: effects on the soil biological properties. J Environ Qual 35:1010-1017. https://doi.org/10.2134/ jeq2005.0460
Wang J, Mao H, Zhao H, Huang D, Wang Z (2012) Different increases in maize and wheat grain zinc concentrations caused by soil and foliar applications of zinc in Loess Plateau, China. Field Crop Res 135:89-96. https://doi.org/10.1016/j.fcr.2012.07.010

Weaver CM, Kannan S (2002) Phytate and mineral bioavailability. Food Phytates 2002:211-223. https://doi.org/10.1201/97814 20014419.ch13

White PJ, Broadley MR (2009) Biofortification of crops with seven mineral elements often lacking in human diets-iron, zinc, copper, calcium, magnesium, selenium and iodine. New Phytol 182:49-84. https://doi.org/10.1111/j.1469-8137.2008.02738.x

Whittig L, Allardice W, Klute A (1986) Methods of soil analysis: part 1. Phys Mineral Methods 8:9. https://doi.org/10.1097/00010694198808000-00014

Zhang Y, Shi R, Rezaul KM, Zhang F, Zou C (2010) Iron and zinc concentrations in grain and flour of winter wheat as affected by foliar application. J Agric Food Chem 58:12268-12274. https:// doi.org/10.1021/jf103039k

Zhang YQ, Pang LL, Yan P, Liu DY, Zhang W, Yost R, Zhang FS, Zou CQ (2013) Zinc fertilizer placement affects zinc content in maize plant. Plant Soil 372:81-92. https://doi.org/10.1007/s1110 4-013-1904-9

Zhao A, Tian X, Cao Y, Lu X, Liu T (2014) Comparison of soil and foliar zinc application for enhancing grain zinc content of wheat when grown on potentially zinc-deficient calcareous soils. J Sci Food Agric 94:2016-2022. https://doi.org/10.1002/jsfa.6518

Publisher's Note Springer Nature remains neutral with regard to urisdictional claims in published maps and institutional affiliations. 